\title{
Inventory of native and mother trees in Key Biodiversity Areas of Cebu Island, Philippines for species selection in local reforestation programs
}

\author{
EDGARDO P. LILLO ${ }^{1,2}$, ARCHIEBALD B. MALAKI ${ }^{1,3}$, STEVE MICHAEL T. ALCAZAR ${ }^{1,3}$, \\ RAAMAH ROSALES ${ }^{4}$, BERNARDO R. REDOBLADO ${ }^{1,}$, JOHN LOU B. DIAZ ${ }^{1}$, ERWIN M. PANTINOPLE ${ }^{1}$, \\ INOCENCIO E. BUOT JR..$^{5, \bullet}$ \\ ${ }^{1}$ Cebu Technological University. Argao Campus, Argao 6021, Cebu, Philippines \\ ${ }^{2}$ Forest Biological Sciences, College of Forestry and Natural Resources, University of the Philippines Los Baños. College Laguna 4031, Laguna, \\ Philippines \\ ${ }^{3}$ School of Environmental Science and Management, University of the Philippines Los Baños. College Laguna 4031, Laguna, Philippines \\ ${ }^{4}$ Cebu Technological University. Main Campus, Cor R. Palma Street, Cebu 6000, Philiipines \\ ${ }^{5}$ Institute of Biological Sciences, University of the Philippines Los Baños College. Laguna 4031, Laguna, Philippines. Tel: +63-9228140447. \\ vemail: iebuot@up.edu.ph, edgardo.lillo@ctu,edu.ph
}

Manuscript received: 16 August 2021. Revision accepted: 11 October 2021.

\begin{abstract}
Lillo EP, Malaki AB, Alcazar SMT, Rosales R, Redoblado BR, Diaz JLB, Pantinople EM, Buot Jr. IE. 2021. Inventory of native and mother trees in Key Biodiversity Areas of Cebu Island, Philippines for species selection in local reforestation programs. Biodiversitas 22: 4740-4749. Forest restoration is the counterforce of deforestation and forest degradation. Yet, despite promoting natural recovery after forest harvest, afforestation and reforestation efforts, tropical forest ecosystems still experience a poor ratio of forest loss to forest gain. The study assessed the native tree species and potential mother trees in different Cebu Island Key Biodiversity Areas (KBAs) as well as their distribution and habitat preferences which can be used in local reforestation programs. A vegetation survey was conducted in three KBAs in Cebu Island, namely Nug-as forest, Mount Lantoy and Mount Capayas to inventory all native species. Assessment based on the phenotypic characteristics of adult trees was also conducted for indicating mother trees. This study in Cebu Island KBAs recorded a total of 292 species, categorized into 125 families and 203 genera, which can be classified into native trees (210), vines and lianas (18), shrub (37), and herbs (27). Out of the 292 species, 214 were recorded in Nug-as forest, 172 in Mount Lantoy, and 145 in Mount Capayas. Of the 210 native tree species, Nug-as forest had 145 species, Mount Lantoy 131 species, and Mount Capayas 109 species. A total of 241 mother trees were identified in the three KBAs, corresponding to 77 species in which Nug-as forest had 143 trees correspond to 52 species, Mount Lantoy had 68 trees correspond to 29 species, and Mount Capayas had 31 trees correspond to 6 species. Such native tree species are recommended for reforestation programs as planting materials that could reduce the risks of failure due to its high adaptability to the environment.
\end{abstract}

Keywords: Elevation, mother trees, Mount Capayas, Mount Lantoy, Nug-as forest

\section{INTRODUCTION}

Government programs on reforestation are important activities in solving the degradation problem resulting from many decades of deforestation (Hansen et al. 2013). Tropical forests are disappearing at alarming rates worldwide, reducing annually by $1-4 \%$ of their current area through relatively increased anthropogenic pressures (Anitha et al. 2010). Keenan (2015) reported that the recent results of the Global Forest Resources Assessment indicate that the natural forest area was still declining from 3,961 to 3,721 million hectares between 1990 and 2015. The situation also occurs in the Philippines which suffered forest loss in the past centuries. Based on the revised Master Plan of the Philippines for Forestry Development, the percent forest cover in 1575 was still 92\%, and in 2003 it was reduced to $24 \%$ (FMB-DENR 2015), meaning that the forest cover declined at an average annual rate of $47,429.91$ hectares in 428 years.

There have been various efforts conducted to counterforce deforestation and forest degradation globally. Nonetheless, Hansen et al. (2013) found that from 2000 to
2010 period, tropical forests ecosystems still experience a poor ratio between forest loss and forest gain with ratio of 3.6:1. Chazdon et al. (2015) emphasize that the continuing deforestation and forest degradation with less forest increase have put pressures on biodiversity, ecosystem goods and services, as well as forest-based livelihoods. For example, in Cebu Island, the Philippines from 2001 to 2020 it lost 9,170 hectares of the forest, equivalent to a $4.3 \%$ decrease in tree cover and $4.66 \mathrm{Mt}$ of $\mathrm{CO}_{2}$ emissions (Global Forest Watch 2020).

Citing the situation above, forest restoration could be considered as a cornerstone for global biodiversity conservation and sustainable development (Aronson and Alexander 2013; Suding et al. 2015). Taking about forest restoration, the Convention on Biological Diversity through Aichi Target 15, UN REDD+ program and the New York Declaration on Forests have pledged to restore 150 million hectares of deforested and degraded forestland worldwide in 2020, and 350 million hectares by 2030 (Bonn Challenge 2016; Jacobs et al. 2015). In the Philippines, the target area for reforestation is 1.5 million hectares nationwide which are to be planted by 1.5 billion trees of combined forest 
species and fruit trees for a period of six years with a total budget of 5 billion pesos (DENR NGP Website).

Van Breugel (2011) and Soejono \& Arisoesilaningsih (2013), emphasizing that in forest restoration, there is a need for scientific information on more appropriate tree species selection and species mixtures. However, according to Meli et al. (2017) and Stanturf et al. (2014), the selection of native species for forest restoration is much more complicated and challenging than the selection of plant materials for monoculture plantations. Wingfield (2015) reiterates that monoculture plantations increase risks associated with pest and pathogen outbreaks, and threatens the conservation of many forest-dependent species. Nichols and Vanclay (2012) also emphasize that there have been calls for native rainforest trees to be domesticated and planted as an alternative to the large-scale mixed and monocultures that have dominated in the tropics for decades. Further, Bozzano et al. (2014) state that for largescale reforestation and landscape restoration projects, native trees are therefore be preferred.

Evaluating and updating data on native tree species are essentials to support conservation plans and programs for local reforestation (Hyvärinen et al. 2011; Lestari et al. 2019). Based on the study of Schneider et al. (2014), reforestation programs under community forestry in the Philippines that used native species combined with some exotic fruit trees as the planting materials have shown great success through the form of "rainforestation farming system" since it supported the livelihoods of the local community by selling the fruits and seedlings. Nonetheless, in some areas in the country, information on the composition and distribution of native trees is inadequate to support such a program, including in Cebu Island. The study aimed to assess the available native tree species and potential mother trees in different Cebu Island Key Biodiversity Area's (KBA) and to investigate their distribution and habitat preferences. The results of this study are expected to serve as baseline information for species-site suitability in local reforestation programs.

\section{MATERIALS AND METHODS}

\section{Study area}

The study was conducted in the Key Biodiversity Area (KBA's) of Cebu Island Philippines. The site includes: Mt. Lantoy of the Municipality of Argao (09549' N, 123329' $\mathrm{E})$, with an elevation ranges from $100-700 \mathrm{~m}$, Nug-as forest of the Municipality of Alcoy $\left(09^{\circ} 71^{\prime} \mathrm{N}, 123^{\circ} 44^{\prime} \mathrm{E}\right)$ ranges from 500-960m, and Mount Capayas Key Biodiversity Area (KBA), lies at coordinates $10^{\circ} 38^{\prime} 34.296^{\prime \prime} \mathrm{N}$, and $123^{\circ} 56^{\prime} 32.784^{\prime \prime} \mathrm{E}$, elevation ranges from 200 to $725 \mathrm{~m}$ (Figure 1).

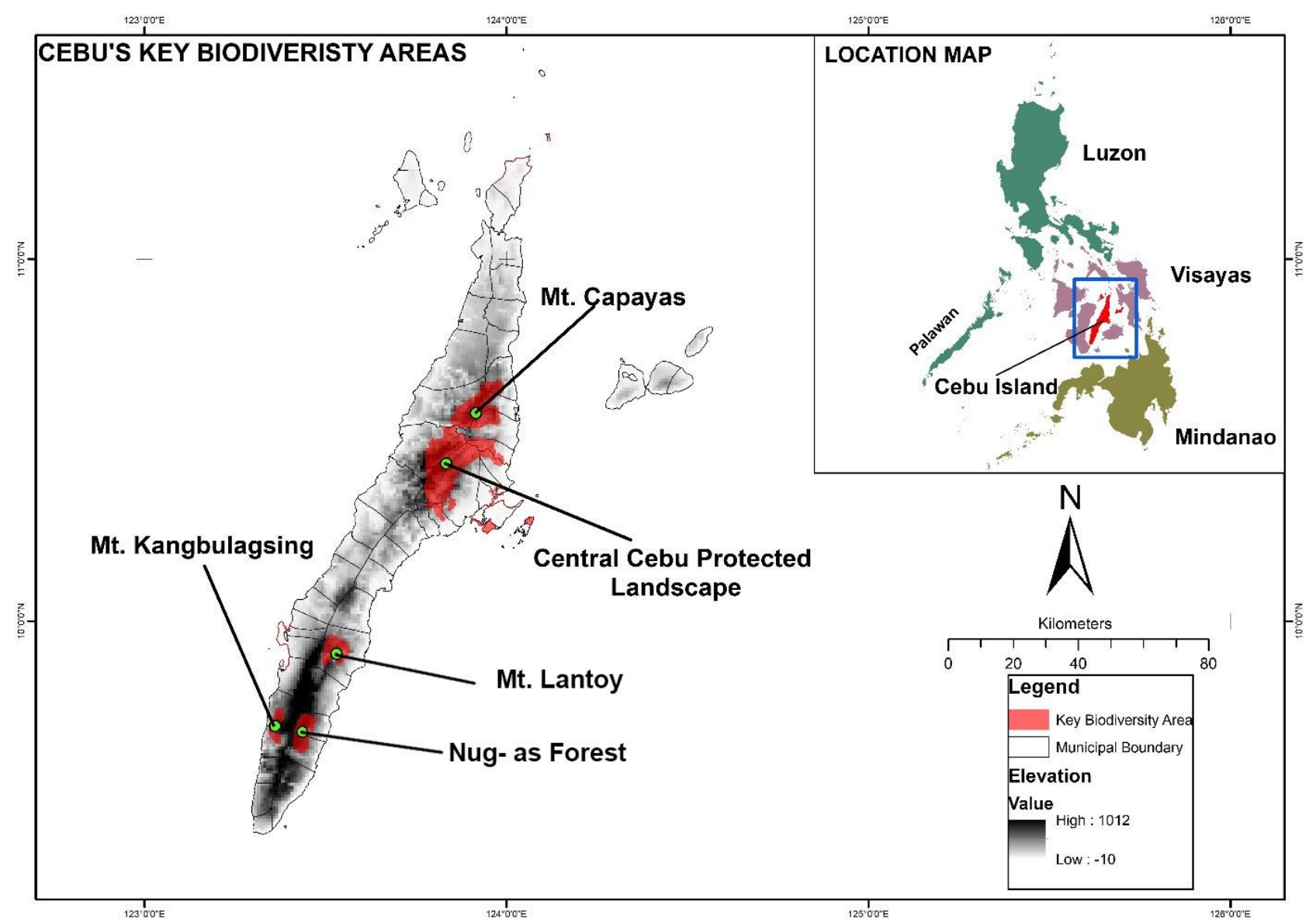

Figure 1. Map of the study location in different Key Biodiversity Areas in the Island of Cebu, the Philippines 
Table 1. Criteria and corresponding parameters measured to assess the physical quality of the mother trees (Department Administrative Order No. 95-09 1995)

\begin{tabular}{ll}
\hline Criterion & Parameter \\
\hline Stem growth & $\begin{array}{l}\text { Total height }(\mathrm{m}) \\
\text { Diameter at breast height }(\mathrm{cm})\end{array}$ \\
Stem form & $\begin{array}{l}\text { Stem straightness } \\
\text { Forking } \\
\text { Circularity of the stem }\end{array}$ \\
Health & Tree health \\
Branching characteristics & $\begin{array}{l}\text { Branch angle } \\
\text { Branch thickness } \\
\text { Branch persistence }\end{array}$ \\
\hline
\end{tabular}

\section{Field data collection}

Permanent plots were established in the lower $(200 \mathrm{~m}$ asl and below), middle (201-500 $\mathrm{m}$ asl), and upper elevation (501 $\mathrm{m}$ asl and above) areas of the different KBAs. The highest elevation in the three KBAs was $800 \mathrm{~m}$ asl in Mount Lantoy, Mount Capayas was $700 \mathrm{~m}$ asl, and $900 \mathrm{~m}$ asl in Nug-as Forest (Lillo et al. 2020). The size of the plot was $20 \mathrm{~m} \mathrm{x} 100 \mathrm{~m}$, and a total of 8 plots were established in each KBA. Each sampling plot was further divided into five equal segments $(20 \mathrm{~m} \times 20 \mathrm{~m})$ to facilitate recording plants in the canopy layer having a diameter at breast height $(\mathrm{DBH})$ of $10 \mathrm{~cm}$ and above. On the other hand, a nested subplot of $5 \mathrm{~m} \times 5 \mathrm{~m}$ was laid at the center of each segment for data recording of plants in the intermediate layer having DBH of less than $10 \mathrm{~cm}$. Data recorded in the field were: (i) plant names from family down to species level; and (ii) bio-measurements on diameter at breast height $(\mathrm{cm})$ and total height $(\mathrm{m})$ as one of the criteria in the selection of potential mother trees (Department Administrative Order No. 95-09 1995).

\section{Assessment of the phenotypic characteristics of the mother trees}

The selection of phenotypic characteristics for mother trees was based on the method developed by DENR (Department Administrative Order No. 95-09 1995). The evaluation of the phenotypic characteristics was focused on the stem growth, stem form, health and branching characteristics as stipulated in Table 1.

\section{Locations, distribution, and marking of mother trees}

The location and distribution of individual native species, as well as the mother trees in each site, were indicated on the map. The ground coordinates as well as the elevation of each plot were determined using GPS. The plot was oriented in the North-East direction to easily estimate the local coordinates of individual trees within the plot. The local coordinates of each native tree and identified mother trees within the plot were determined by adding the $X$ and $Y$ distances (Lillo et al. 2019).

\section{RESULTS AND DISCUSSION}

\section{Habitat characteristics}

Mt. Lantoy KBA of the Municipality of Argao in general is characterized as mountainous topography dominated by Carcar formation with the forest over limestone at elevation ranges from 100-800 m asl (Lillo et al. 2019). Mount Lantoy has a geological composition of mostly raised sedimentary and metamorphic rocks - a considerable part of it being limestone (Lillo et al. 2019). The habitat type is comparable to the forest over limestone of the Philippines forest formation of Fernando et al. (2008). According to Lillo et al. (2019), Mount Lantoy is also covered by large size outcrop bedrocks with shallow soil and undecomposed organic matters. The site was covered by smaller to larger diameter trees with diameters ranging from $11-80 \mathrm{~cm}$ in terms of vegetation. The observation plot was covered by vegetation (50\%), canopy cover of $80 \%$, and an understory of $30 \%$. The plot, in general, was characterized as closed canopy cover, allowing less amount of solar radiation to infiltrating into the ground surface

Nug-as Forest KBA of the Municipality of Alcoy is characterized as forest over limestone and tropical lowland evergreen forest with elevation ranges from 200 to $960 \mathrm{~m}$ asl. The forest over limestone as described by Lillo et al. (2020) is located in the forest edge as well as in the mountain ridge of the forest. In comparison, the tropical lowland evergreen forest was found dominating in the whole area. According to Lillo et al. (2020), Nug-as forest has a total land area of 1,600 ha, but 800 ha was already covered by established plantations as well as by shrub vegetation. The forest vegetation type can be characterized as secondary forest similar to Mount Lantoy (Lillo et al. 2020). Nug-as forest was covered by trees with a diameter ranging from $15-80 \mathrm{~cm}$ which were overall larger and taller among KBAs in the Island of Cebu. The forest was densely covered by vegetation (70\%) and a canopy cover of $60 \%$.

Mount Capayas KBA of the Municipality of Catmon was characterized as forest over limestone habitat types at elevation ranges from 200 to $725 \mathrm{~m}$ asl or described as mountainous topography. Its geological composition was mostly raised sedimentary and metamorphic rocks and was covered by the large size of outcrop bedrocks with shallow soil and undecomposed organic matters similar to Mount Lantoy KBA. The habitat type description can be characterized as karst topography and conformed to the forest over limestone of the Philippines (Fernando et al. 2008). Mount Capayas KBA was covered by less dense vegetation $(40 \%)$ with a canopy cover of $50 \%$ and small size trees and few large trees ranging from $10-40 \mathrm{~cm}$.

\section{Composition of native trees}

A total species of 292, classified into 125 families and 203 genera were recorded in Cebu Island. Out of 292 species, 210 are native trees, 18 vines and lianas, 37 shrub, and 27 herbs. The majority of the species were recorded in Nug-as forest KBA with 214 species, 172 in Mount Lantoy, and 145 in Mount Capayas. Of the 210 native tree species, 145 were recorded in Nug-as forest, 131 in Mount 
Lantoy and 109 in Mount Capayas. Native trees were classified as endemic and non-endemic indigenous species. Non-endemic indigenous were those species recorded in the country and other countries, but the method of distribution was due to natural processes (Lillo et al. 2019).

Native trees in Cebu Island were equivalent to $3 \%$ of the total number of vascular plant species native to the Philippines with 9,250 species (Conservation International 2021). Comparing the result to Dinagat Island, which is considered one of the most botanically diverse islands in the Philippines with 432 native plant species (Lillo et al. 2019), it was equivalent to $68 \%$. The result implies that Cebu Island also serves as a habitat for endemic native tree species, which need to be conserved and protected.

Among the 292 species, the most recorded genera were Ficus, Cinnamomum and Artocarpus. For families, the most dominant were Moraceae, Rubiaceae, and Lauraceae. In the case of species, Cebu Island KBAs were dominated by Ficus ampelas Burm.f, Neonauclea calycina (Bartl. ex DC.) Merr, and Psychotria gitingensis Elmer. All the dominant species were considered pioneer species which serve as an indicator of a secondary growth forest (https://www.philippineplants.org/).

\section{Mother trees per Key Biodiversity Area}

Based on the phenotypic criteria of mother trees as stipulated in Department Administrative Order No. 95-09 (1995), a total of 241 potential native mother trees were identified in three KBAs, corresponding to 77 species.

\section{Nug-as forest KBA}

In Nug-as forest KBA of the Municipality of Alcoy, Cebu, a total of 143 individual native trees correspond to 52 species that passed the criteria as the mother tree. The dominant mother trees in terms of frequency both for large and small trees were the following: Palaquium foxworthyi Merr., Planchonella macrantha (Merr.) Swenson, Calophyllum blancoi Planch. \& Triana, Litsea cordata (Jack) Hook, Shorea polysperma (Blanco) Merr. Anisoptera thurifera (Blanco) Blume, Canarium asperum Benth. Elaeocarpus cumingii Turcz., Gomphandra mappioides Valeton, Lithocarpus robinsonii Rehder, Magnolia liliifera (L.) Baill., Magnolia philippinensis P.Parm., Myristica nivea Merr., Myristica philippensis Lamk. Streblus glaber (Merr.) Corner, and Syzygium lineatum (Roxb.) Merr. \& Perry (Table 2). The abovementioned species had a diameter ranges from 20 to $80 \mathrm{~cm}$ and total height ranges from 15 to $20 \mathrm{~m}$. The trees had merchantable height ranges from 5 to $10 \mathrm{~m}$ with rounded and monopodial stem characteristics (Figure 2).

Shorea polysperma (Blanco) Merr., Anisoptera thurifera (Blanco) Blume, Palaquium foxworthyi Merr., Planchonella macrantha (Merr.) Swenson, Tristaniopsis littoralis (Merr.) Wils. \& Waterh., Lithocarpus robinsonii Rehder, and Elaeocarpus cumingii Turcz. were the species exhibit larger diameter and taller height than other mother trees (Figure 2).
The species of Palaquium foxworthyi Merr., Planchonella macrantha (Merr.) Swenson, Calophyllum blancoi Planch. \& Triana, Litsea cordata (Jack) Hook, Merr., Canarium asperum Benth., Elaeocarpus cumingii Turcz., Gomphandra mappioides Valeton, Magnolia liliifera (L.) Baill., Magnolia philippinensis P.Parm., Myristica nivea Merr., Myristica philippensis Lamk. Streblus glaber (Merr.) Corner, and Syzygium lineatum (Roxb.) Merr. \& Perry were recorded from lower to middle elevation. While Gymnostoma rumphianum (Miq.) L.A.S.Johnson was recorded both in lower and middle elevation of the site (Table 2). The result on the location and distribution of the species is confirmed on the records of the species in the Philippine plant database (https://www.philippineplants.org/).

Whereas the species of Shorea polysperma (Blanco), Lithocarpus robinsonii Rehder, Anisoptera thurifera (Blanco) Blume, and Agathis philippinensis Warb were recorded in upper elevation (Table 2). The result of the study was confirmed on the records of the species in Philippine plant database (https://www.philippineplants.org/) that Shorea polysperma and Anisoptera thurifera (Blanco) Blume found as medium-sized trees were distributed mostly in the upper elevation of the forest. In contrast, Agathis species grow well in full sunlight unlike most other dipterocarp species and are classified as early-successional species (Schneider et al. 2014).

Shorea polysperma (Blanco), and Anisoptera thurifera (Blanco) Blume species belong to Dipterocarpaceae family. Dipterocarpaceae is one of the plant families that ranked high in community importance (Hamann 2015). The family was also known as the Philippine mahogany group in the Philippines because they were considered the most important tropical timber species. They were primarily used locally for construction and furniture making (Hamann 2015). Nowadays, only a few remnants of dipterocarp forests are left in the Philippine archipelago. The result of the study implies that remnants of the Dipterocarpaceae species were also recorded in the Key Biodiversity Areas of Cebu Island which could be used as the source of planting materials for reforestation. Using highly valued native species in reforestation programs can restore the original economic and ecological potential of the communities (Schneider et al. 2014). In Sarawak, Malaysia Dipterocarpaceae species performed high survival rate (86-88\%) in forest rehabilitation programs (Wasli 2014).

Dysoxylum pauciflorum Merr., Garcinia binucao (Blanco) Choisy, Lithocarpus robinsonii Rehder, Myristica philippensis Lamk., Neolitsea intermedia Elmer, Palaquium foxworthyi Merr., Shorea polysperma (Blanco) Merr., and Tristaniopsis littoralis (Merr.) Wils. \& Waterh were categorized as endemic species to the Philippines (Table 2). At the same time, Cinnamomum cebuensis Kosterm was endemic to Cebu Island (https://www.philippineplants.org/). Endemic species to be used as planting material for reforestation programs can ensure a higher survival rate because of their high adaptability to the environment (Ostertag 2015) 
Table 2. List of identified species, location and endemicity of mother trees in Nug-as Forest KBA, Cebu, Philippines

\begin{tabular}{|c|c|c|c|c|c|}
\hline \multirow[b]{2}{*}{ Identified Mother trees } & \multirow[b]{2}{*}{ Frequency } & \multicolumn{3}{|c|}{ Elevation } & \multirow{2}{*}{$\begin{array}{c}\text { Endemicity } \\
\text { (https://www. } \\
\text { Philippineplants. } \\
\text { org/) }\end{array}$} \\
\hline & & $\begin{array}{c}\text { Lower } \\
\text { (below 200 } \\
\text { m asl) } \\
\end{array}$ & $\begin{array}{c}\text { Middle } \\
(201-500 \mathrm{~m} \\
\text { asl }) \\
\end{array}$ & $\begin{array}{c}\text { Upper } \\
\text { (501 m asl) }\end{array}$ & \\
\hline Agathis philippinensis Warb. & 1 & & & $\mathrm{x}$ & $\mathrm{NE}$ \\
\hline Aglaia rimosa (Blanco) Merr. & 2 & & & $\mathrm{x}$ & $\mathrm{NE}$ \\
\hline Anisoptera thurifera (Blanco) Blume & 5 & & & $\mathrm{x}$ & $\mathrm{NE}$ \\
\hline Arthrophyllum ahernianum Merr. & 1 & $\mathrm{x}$ & $\mathrm{x}$ & & $\mathrm{NE}$ \\
\hline Artocarpus sericicarpus F.M.Jarrett & 1 & $\mathrm{x}$ & $\mathrm{x}$ & & NE \\
\hline Buchanania microphylla Engl. & 1 & $\mathrm{x}$ & $\mathrm{x}$ & & $\mathrm{NE}$ \\
\hline Calophyllum blancoi Planch. \& Triana & 6 & $\mathrm{x}$ & $\mathrm{x}$ & & NE \\
\hline Canarium asperum Benth. & 4 & $\mathrm{x}$ & $\mathrm{x}$ & & $\mathrm{NE}$ \\
\hline Cinnamomum cebuensis Kosterm. & 2 & $\mathrm{x}$ & $\mathrm{x}$ & & $\mathrm{PE}(\mathrm{Cebu})$ \\
\hline Dysoxylum pauciflorum Merr. & 3 & $\mathrm{x}$ & $\mathrm{x}$ & & PE \\
\hline Elaeocarpus cumingii Turcz. & 8 & $\mathrm{x}$ & $\mathrm{x}$ & & $\mathrm{NE}$ \\
\hline Ficus ampelas Burm.f. & 1 & $\mathrm{x}$ & $\mathrm{x}$ & & NE \\
\hline Ficus benjamina $\mathrm{L}$. & 1 & $\mathrm{x}$ & $\mathrm{x}$ & & NE \\
\hline Ficus callosa Willd. & 2 & $\mathrm{x}$ & $\mathrm{x}$ & & NE \\
\hline Ficus chrysolepis Miq & 2 & $\mathrm{x}$ & $\mathrm{x}$ & & NE \\
\hline Ficus variegata Blume & 1 & $\mathrm{x}$ & $\mathrm{x}$ & & $\mathrm{NE}$ \\
\hline Garcinia binucao (Blanco) Choisy & 2 & $\mathrm{x}$ & $\mathrm{x}$ & & $\mathrm{PE}$ \\
\hline Garcinia rubra Merr. & 1 & $\mathrm{x}$ & $\mathrm{x}$ & & $\mathrm{PE}$ \\
\hline Glochidion album (Blanco) Boerl & 1 & $\mathrm{x}$ & $\mathrm{x}$ & & NE \\
\hline Gomphandra mappioides Valeton & 6 & $\hat{x}$ & $\mathrm{x}$ & & $\mathrm{NE}$ \\
\hline Guioa koelreuteria (Blanco) Merr. & 1 & $\mathrm{x}$ & $\mathrm{x}$ & & NE \\
\hline Gymnostoma rumphianum (Miq.) L.A.S.Johnson & 2 & & $\mathrm{x}$ & $\mathrm{x}$ & NE \\
\hline Heritiera sylvatica $\mathrm{S}$.Vidal & 1 & $\mathrm{x}$ & $\mathrm{x}$ & & NE \\
\hline Homalanthus populneus (Geisel) & 1 & $\mathrm{x}$ & $\mathrm{x}$ & & NE \\
\hline Lepiniopsis ternatensis Valeton & 2 & $\mathrm{x}$ & $\mathrm{x}$ & & NE \\
\hline Lithocarpus robinsonii Rehder & 5 & & & $\mathrm{x}$ & $\mathrm{PE}$ \\
\hline Litsea cordata (Jack) Hook & 6 & $\mathrm{x}$ & $\mathrm{x}$ & & $\mathrm{NE}$ \\
\hline Magnolia liliifera (L.) Baill. & 5 & $\mathrm{x}$ & $\mathrm{x}$ & & NE \\
\hline Magnolia philippinensis P.Parm. & 4 & $\mathrm{x}$ & $\mathrm{x}$ & & NE \\
\hline Myristica nivea Merr. & 5 & $\mathrm{x}$ & $\mathrm{x}$ & & NE \\
\hline Myristica philippensis Lamk. & 4 & $\mathrm{x}$ & $\mathrm{x}$ & & PE \\
\hline Neolitsea intermedia Elmer & 1 & $\mathrm{x}$ & $\mathrm{x}$ & & $\mathrm{PE}$ \\
\hline Neonauclea calycina (Bartl. Ex DC.) Merr. & 2 & $\mathrm{x}$ & $\mathrm{x}$ & & NE \\
\hline Palaquium foxworthyi Merr. & 11 & $\mathrm{x}$ & $\mathrm{x}$ & & $\mathrm{PE}$ \\
\hline Palaquium obovatum (Griff.) Engl. & 3 & $\mathrm{x}$ & $\mathrm{x}$ & & $\mathrm{NE}$ \\
\hline Pangium edule Reinw. & 1 & $\mathrm{x}$ & $\mathrm{x}$ & & NE \\
\hline Pittosporum pentandrum (Blanco) Merr. & 1 & $\mathrm{x}$ & $\mathrm{x}$ & & NE \\
\hline Planchonella duclitan (Blanco) Bakh.f. & 2 & $\mathrm{x}$ & $\mathrm{x}$ & & $\mathrm{NE}$ \\
\hline Planchonella macrantha (Merr.) Swenson & 11 & $\mathrm{x}$ & $\mathrm{x}$ & & NE \\
\hline Pometia pinnata J.R.Forst. \& G.Forst. & 1 & $\mathrm{x}$ & $\mathrm{x}$ & & $\mathrm{NE}$ \\
\hline Shorea almon Foxw. & 2 & & & $\mathrm{x}$ & $\mathrm{NE}$ \\
\hline Shorea polysperma (Blanco) Merr. & 4 & & & $\mathrm{x}$ & $\mathrm{PE}$ \\
\hline Streblus glaber (Merr.) Corner & 5 & $\mathrm{x}$ & $\mathrm{x}$ & & $\mathrm{NE}$ \\
\hline Syzygium calubcob (C.B.Rob.) Merr. & 1 & $\mathrm{x}$ & $\mathrm{x}$ & & $\mathrm{NE}$ \\
\hline Syzygium lineatum (Roxb.) Merr. \& Perry & 4 & $\hat{\mathrm{x}}$ & $\mathrm{x}$ & & NE \\
\hline Syzygium simile (Merr.) Merr. & 2 & $\mathrm{x}$ & $\mathrm{x}$ & & $\mathrm{NE}$ \\
\hline Syzygium toppingii (Elmer) Merr. & 2 & $\mathrm{x}$ & $\mathrm{x}$ & & NE \\
\hline Tristaniopsis littoralis (Merr.) Wils. \& Waterh. & 1 & $\mathrm{x}$ & $\mathrm{x}$ & & $\mathrm{PE}$ \\
\hline Vavaea amicorum Benth. & 2 & $\mathrm{x}$ & $\mathrm{x}$ & & $\mathrm{NE}$ \\
\hline Total & 143 & & & & \\
\hline
\end{tabular}




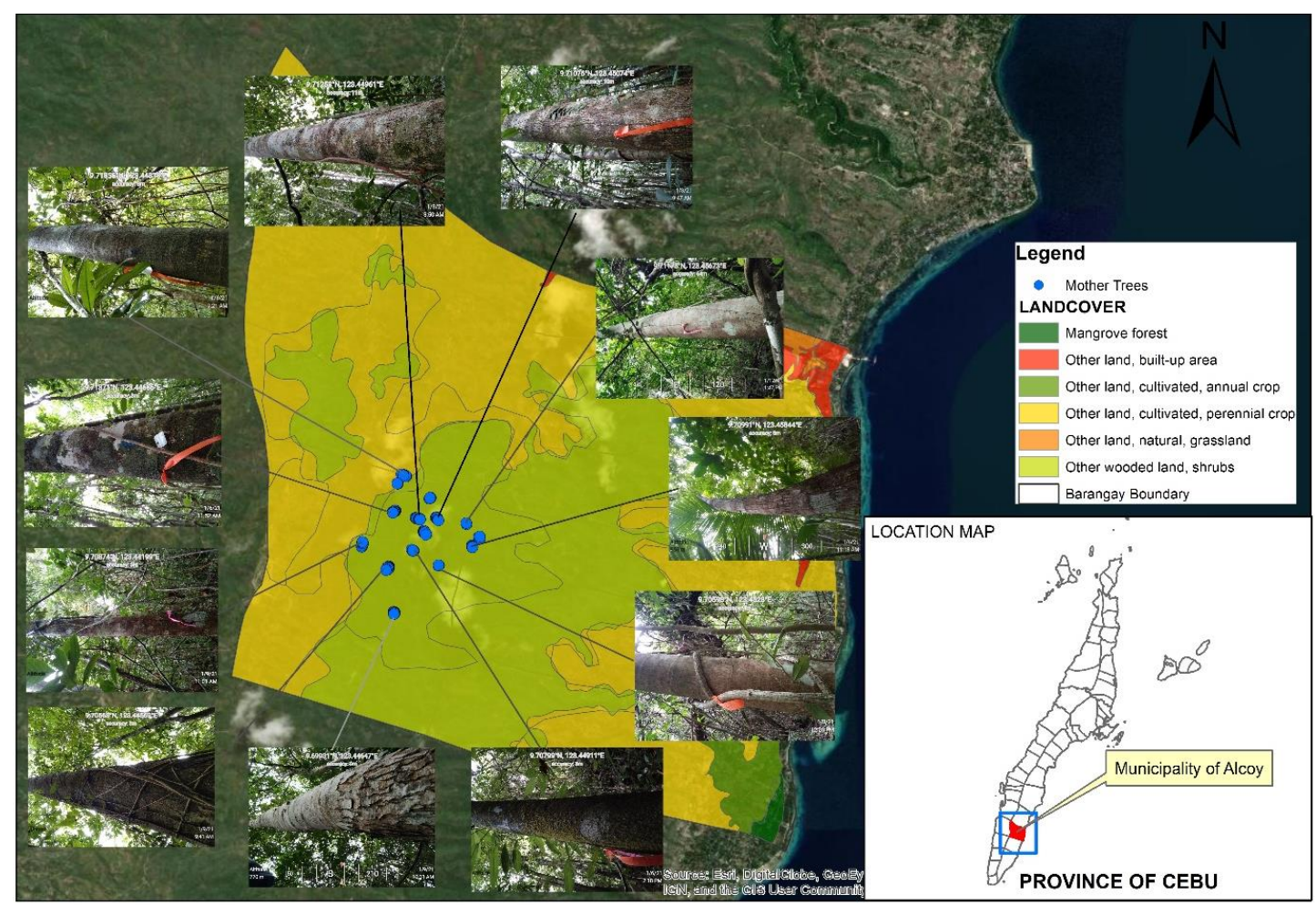

Figure 2. Map of location and distribution of identified mother trees in Nug-as Forest KBA, Cebu, Philippines

\section{Mount Lantoy KBA}

In Mount Lantoy KBA of the Municipality of Argao, Cebu, a total of 68 individual native trees correspond to 29 species that passed the criteria as mother trees (Table 3). The dominant mother trees in terms of frequency were Anisoptera thurifera (Blanco) Blume, Buchanania microphylla Engl, Canarium asperum Benth, Dysoxylum pauciflorum Merr, Intsia bijuga (Colebr.) Kuntze, Palaquium foxworthyi Merr., Parishia malabog Merr., Shorea almon Foxw., Turpinia sphaerocarpa Hassk., Vatica manggachapoi Blanco, Shorea contorta S.Vidal, Shorea guiso, and Wallaceodendron celebicum Koord. Those species had a diameter ranges from 20 to $70 \mathrm{~cm}$ and total height ranges from 10 to $15 \mathrm{~m}$. The trees have merchantable height ranges from 4 to $7 \mathrm{~m}$ with rounded and monopodial stem characteristics (Figure 3), slightly smaller in diameter and height as compared to Nug-as Forest.

The species of Canarium asperum Benth, Buchanania microphylla Engl, Dysoxylum pauciflorum Merr, Intsia bijuga (Colebr.) Kuntze., Palaquium foxworthyi Merr., and Parishia malabog Merr., were recorded in lower to the middle elevation of the site. Similar species were also recorded in Nug-as forest in the same elevation. Whereas the species of Anisoptera thurifera (Blanco) Blume., Shorea almon Foxw., Shorea contorta S.Vidal, Shorea guiso (Blanco) Blume, Turpinia sphaerocarpa Hassk., Vatica manggachapoi Blanco., and Wallaceodendron celebicum Koord were recorded in upper elevation of the site similar to Nug-as forest. The species of Shorea contorta S. Vidal, Anisoptera thurifera (Blanco) Blume, Shorea guiso (Blanco) Blume were common on the upper slope and along the ridge. Shorea almon Foxw mostly occurred together with Shorea palosapis which preferred ridge and especially upper slope habitats (https://www.philippineplants.org/). Similar habitat preference as Vatica mangachapui which is also preferred in ridge and upper slope habitats (https://www.philippineplants.org/).

Shorea contorta S.Vidal, Anisoptera thurifera (Blanco) Blume, Shorea guiso (Blanco) Blume, Shorea almon Foxw, and Shorea polysperma (Blanco) species belong to Dipterocarpaceae family (https://www.philippineplants.org/), which also serve as the most important source of timber in Southeast Asia (Hamann 2015). Dipterocarpaceae species were also adopted by Indonesia for forest rehabilitation and restoration (Daisuke et al. 2013; Kettle 2010). In addition, Widiyatno et al. (2013) state that Dipterocarpaceae species are more resistant to sunlight and hence they could be easily established in open planting that has high heat and temperature stress in the early plantation establishment. Cinnamomum cebuensis Kosterm, Dysoxylum pauciflorum Merr., Lithocarpus robinsonii Rehder, Palaquium foxworthyi Merr., Parishia malabog Merr., Shorea contorta S. Vidal were categorized as endemic species of the Philippines (https://www.philippineplants.org/Families). 


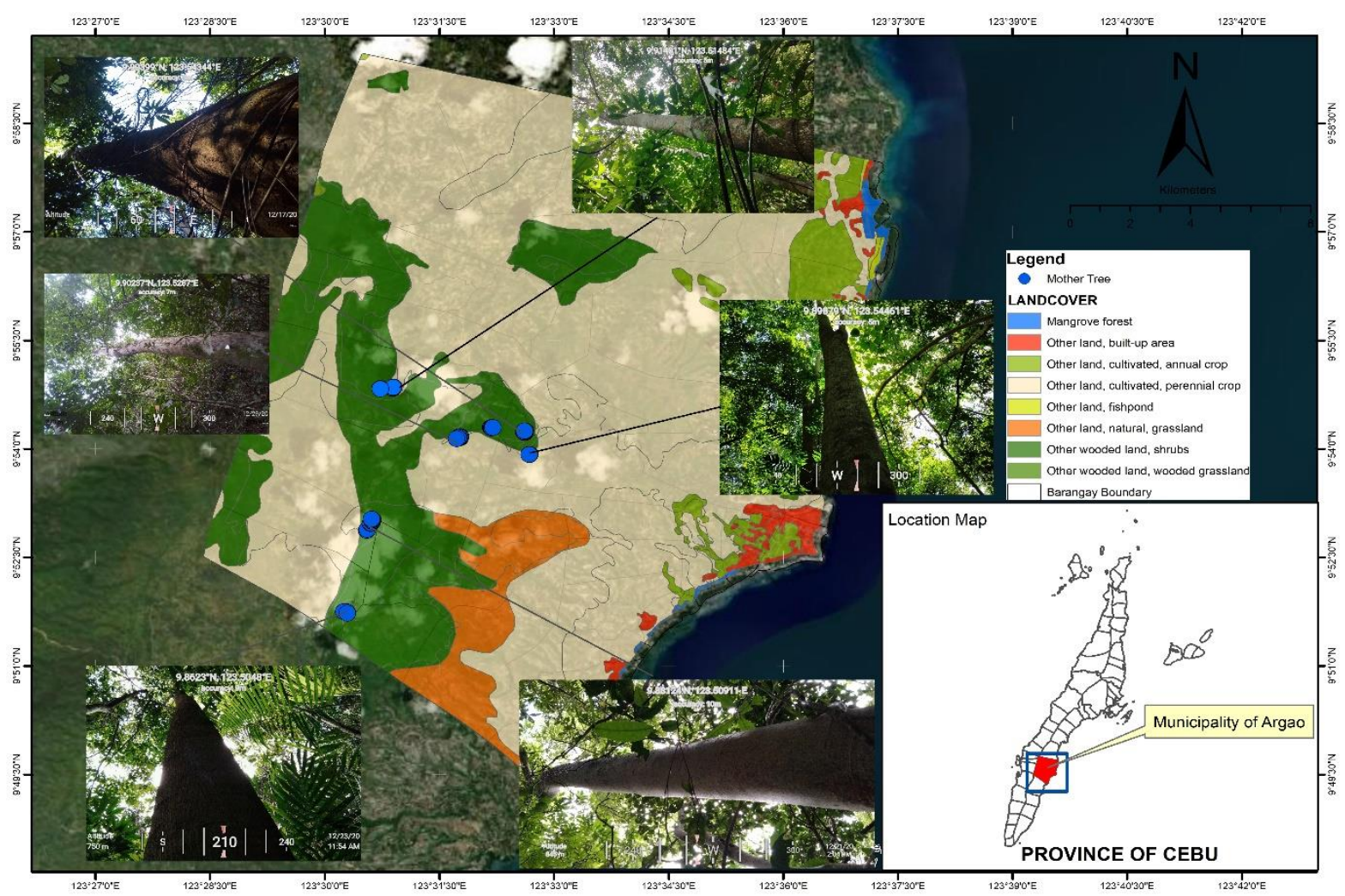

Figure 3. Map of location and ddistribution of identified mother trees in Mount Lantoy KBA, Cebu, Philippines

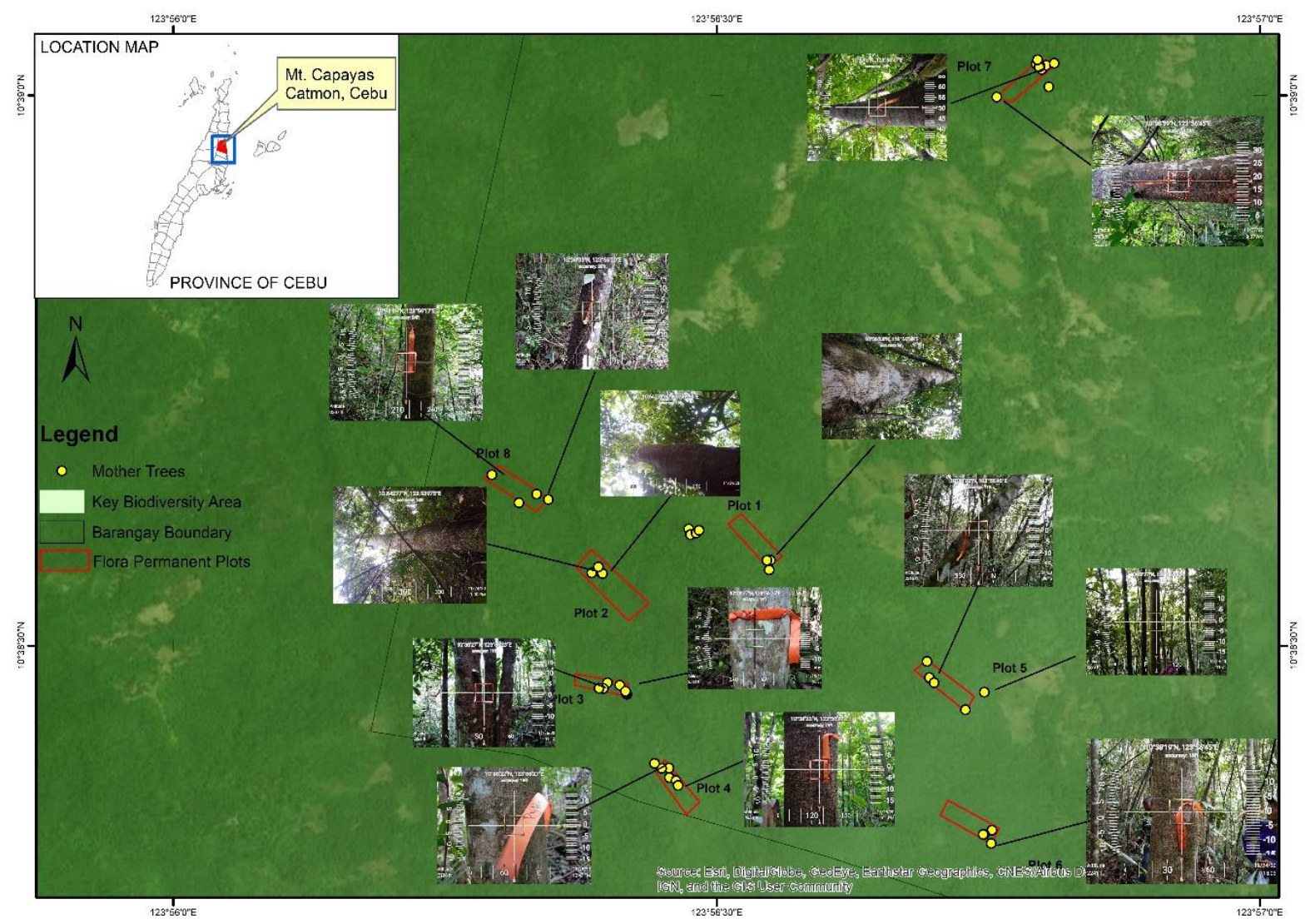

Figure 4. Map of location and distribution of identified mother trees in Mount Capayas, Cebu, Philippines 
Table 3. List of identified species, location and endemicity of mother trees in Mount Lantoy KBA, Cebu, Philippines

\begin{tabular}{|c|c|c|c|c|c|}
\hline \multirow[b]{2}{*}{ Identified mother trees } & \multirow[b]{2}{*}{ Frequency } & \multicolumn{3}{|c|}{ Elevation } & \multirow[b]{2}{*}{$\begin{array}{c}\text { Endemicity } \\
\text { (https://www. } \\
\text { philippineplants.org/) }\end{array}$} \\
\hline & & $\begin{array}{c}\text { Lower } \\
\text { (below 200m } \\
\text { asl) }\end{array}$ & $\begin{array}{l}\text { Middle } \\
(201-500 m \\
\text { asl) }\end{array}$ & $\begin{array}{c}\text { Upper } \\
(501 \mathrm{~m} \text { asl } \\
\text { and } \\
\text { above })\end{array}$ & \\
\hline Alstonia macrophylla Wall. ex G.Don & 1 & $\mathrm{x}$ & $\mathrm{x}$ & & $\mathrm{NE}$ \\
\hline Anisoptera thurifera (Blanco) Blume & 4 & & & $\mathrm{x}$ & NE \\
\hline Buchanania microphylla Engl. & 3 & $\mathrm{x}$ & $\mathrm{x}$ & & NE \\
\hline Canarium asperum Benth. & 3 & $\mathrm{x}$ & $\mathrm{x}$ & & NE \\
\hline Cinnaтотит cebuensis Kosterm. & 1 & & $\mathrm{x}$ & & PE \\
\hline Dysoxylum gaudichaudianum (A.Juss.) Miq. & 1 & $\mathrm{x}$ & & & $\mathrm{NE}$ \\
\hline Dysoxylum pauciflorum Merr. & 5 & $\mathrm{x}$ & $\mathrm{x}$ & & $\mathrm{PE}$ \\
\hline Elaeocarpus cumingii Turcz. & 1 & $\mathrm{x}$ & $\mathrm{x}$ & & NE \\
\hline Ficus ampelas Burm.f. & 2 & $\mathrm{x}$ & $\mathrm{x}$ & & $\mathrm{NE}$ \\
\hline Intsia bijuga (Colebr.) Kuntze & 6 & $\mathrm{x}$ & $\mathrm{x}$ & & $\mathrm{NE}$ \\
\hline Lithocarpus robinsonii Rehder & 1 & & & $\mathrm{x}$ & PE \\
\hline Palaquium foxworthyi Merr. & 4 & $\mathrm{x}$ & $\mathrm{x}$ & & PE \\
\hline Palaquium luzoniensis (F.-Vill.) Vidal & 1 & $\mathrm{x}$ & $\mathrm{x}$ & & $\mathrm{NE}$ \\
\hline Parishia malabog Merr & 3 & $\mathrm{x}$ & $\mathrm{x}$ & & $\mathrm{PE}$ \\
\hline Pittosporum pentandrum (Blanco) Merr. & 1 & $\mathrm{x}$ & $\mathrm{x}$ & & $\mathrm{NE}$ \\
\hline Pittosporum ramiflorum Zoll. ex Miq & 1 & $\mathrm{x}$ & $\mathrm{x}$ & & NE \\
\hline Shorea almon Foxw. & 14 & & & $\mathrm{x}$ & $\mathrm{NE}$ \\
\hline Shorea contorta S.Vidal & 2 & & & $\mathrm{x}$ & PE \\
\hline Shorea guiso (Blanco) Blume & 2 & & & $\mathrm{x}$ & $\mathrm{NE}$ \\
\hline Syzygium lineatum (Roxb.) Merr. \& Perry & 1 & $\mathrm{x}$ & $\mathrm{x}$ & & $\mathrm{NE}$ \\
\hline Terminalia foetidissima Griff. & 2 & $\mathrm{x}$ & $\mathrm{x}$ & & NE \\
\hline Toona calantas Merr. \& Rolfe & 1 & $\mathrm{x}$ & $\mathrm{x}$ & & NE \\
\hline Vatica manggachapoi Blanco & 3 & & & $\mathrm{x}$ & NE \\
\hline Vitex parviflora A.Juss & 1 & $\mathrm{x}$ & & & $\mathrm{NE}$ \\
\hline Wallaceodendron celebicum Koord. & 3 & & & $\mathrm{x}$ & $\mathrm{NE}$ \\
\hline Total & 68 & & & & \\
\hline
\end{tabular}

Table 4. List of Identified species, location and endemicity of mother trees in Mount Capayas KBA, Cebu, Philippines

\begin{tabular}{|c|c|c|c|c|c|}
\hline \multirow[b]{2}{*}{ Identified mother trees } & \multirow[b]{2}{*}{ Frequency } & \multicolumn{3}{|c|}{ Elevation } & \multirow{2}{*}{$\begin{array}{c}\text { Endemicity } \\
\text { (https://www. } \\
\text { philippineplants.or } \\
\text { g/) }\end{array}$} \\
\hline & & $\begin{array}{c}\text { Lower } \\
\text { (below 200m } \\
\text { asl) }\end{array}$ & $\begin{array}{c}\text { Middle } \\
(201-500 m \\
\text { asl) }\end{array}$ & $\begin{array}{c}\text { Upper } \\
\text { (501m asl } \\
\text { and above) }\end{array}$ & \\
\hline Alstonia macrophylla Wall. ex G.Don & 4 & $\mathrm{x}$ & $\mathrm{x}$ & & $\mathrm{NE}$ \\
\hline Aquilaria cumingiana (Decne.) Ridl & 1 & $\mathrm{x}$ & $\mathrm{x}$ & & $\mathrm{PE}$ \\
\hline Artocarpus sericicarpus F.M.Jarrett & 2 & $\mathrm{x}$ & $\mathrm{x}$ & & $\mathrm{PE}$ \\
\hline Cynometra cebuensis F.Seid & 1 & $\mathrm{x}$ & $\mathrm{x}$ & & $\mathrm{PE}$ \\
\hline Dillenia philippinensis Rolfe & 1 & $\mathrm{x}$ & $\mathrm{x}$ & & $\mathrm{NE}$ \\
\hline Elaeocarpus cumingii Turcz. & 4 & $\mathrm{x}$ & $\mathrm{x}$ & & PE \\
\hline Guioa acuminata Radlk. & 1 & $\mathrm{x}$ & $\mathrm{x}$ & & $\mathrm{NE}$ \\
\hline Ormosia calavensis Azaola ex Blanco & 1 & $\mathrm{x}$ & $\mathrm{x}$ & & $\mathrm{NE}$ \\
\hline Palaquium luzoniensis (F.-Vill.) Vidal & 2 & $\mathrm{x}$ & $\mathrm{x}$ & & $\mathrm{NE}$ \\
\hline Parishia malabog Merr & 3 & $\mathrm{x}$ & $\mathrm{x}$ & & $\mathrm{PE}$ \\
\hline Polycias nodosa (Blume) Seem. & 1 & $\hat{x}$ & x & & $\mathrm{NE}$ \\
\hline Pometia pinnata J.R.Forst. \& G.Forst. & 1 & $\mathrm{x}$ & $\mathrm{x}$ & & $\mathrm{NE}$ \\
\hline Pterocymbium tinctorium Merr. & 5 & $\mathrm{x}$ & $\mathrm{x}$ & & $\mathrm{NE}$ \\
\hline Radermachera pinnata (Blanco) Seem. & 2 & $\mathrm{x}$ & $\mathrm{x}$ & & $\mathrm{NE}$ \\
\hline Rhus taitensis Guill. & 1 & $\mathrm{x}$ & $\mathrm{x}$ & & $\mathrm{NE}$ \\
\hline Streblus glaber (Merr.) Corner & 1 & $\mathrm{x}$ & $\mathrm{x}$ & & $\mathrm{NE}$ \\
\hline Total & 31 & & & & \\
\hline
\end{tabular}

\section{Mount Capayas KBA}

In Mount Capayas KBA of the Municipality of Catmon, Cebu, a total of 31 individual native trees correspond to 16 species has passed the criteria as mother trees (Table 4).
Less number of mother trees were identified in the site as compared to Mount Lantoy and Nug-as forest since Mount Capayas had a smaller area of coverage as compared to other Key Biodiversity Areas. 
The dominant mother trees in terms of frequency both for larger trees and wildlings in the site were Alstonia macrophylla Wall. ex G.Don, Artocarpus sericicarpus F.M.Jarrett, Elaeocarpus cumingii Turcz., Palaquium luzoniensis (F.-Vill.) Vidal, Parishia malabog Merr, Pterocymbium tinctorium Merr, and Radermachera pinnata (Blanco) Seem. Those species had a diameter ranges from 15 to $40 \mathrm{~cm}$ and total height ranges from 9 to $15 \mathrm{~m}$. The trees had merchantable height ranges from 3 to $7 \mathrm{~m}$, with rounded and monopodial stem characteristics smaller in diameter and height as compared to both Nug-as Forest and Mount Lantoy KBAs (Figure 4).

All the identified mother trees in the site were located or distributed from lower to middle elevation and none in the upper elevation. The species were almost similar to Mount Lantoy and Nug-as forest KBAs (Table 2, 3, and 4). Majority of the mother trees are endemic to the Philippines (https://www.philippineplants.org/), including Artocarpus sericicarpus F.M.Jarrett, Elaeocarpus cumingii Turcz, Parishia malabog Merr Aquilaria cumingiana (Decne.) Ridl and Cynometra cebuensis F.Seid. The species Cynometra cebuensis F.Seid is endemic to Cebu Island and categorized as Critically Endangered Species (DENR 201711). The species Aquilaria cumingiana (Decne.) Ridl is famous agarwood with potential medicinal value and luxurious perfume (Tropical Plants Data 2021). The species is categorized as Vulnerable (DAO 2017-11) and are mostly distributed in primary forests at low and medium elevation (https://www.philippineplants.org/). The species was only recorded in Mount Capayas and absent in Nug-as forest and Mount Lantoy KBAs. Using this highly valued native species for enrichment planting in a reforestation program could restore the original economic and ecological benefits to local communities (Schneider et al. 2014). The result would imply that once a native species be promoted for a reforestation program it could reduce the risks of failure due to the selection of unsuited habitats.

In conclusion, this study in Cebu Island KBAs recorded a total species of 292, categorized into 125 families and 203 genera. The species were classified into native trees (210), vines and lianas (18), shrub (37), and herbs (27). Out of the 292 species, 214 were recorded in Nug-as forest KBA, 172 in Mount Lantoy KBA, and 145 in Mount Capayas KBA. Of the 210 native tree species, the majority were recorded in Nug-as forest with 145, followed by Mount Lantoy 131, and 109 in Mount Capayas.

Based on the phenotypic criteria of mother trees as stipulated in Department Administrative Order No. 95-09 (1995), a total of 241 potential native mother trees were identified in the three KBAs, corresponding to 77 species. Nug-as forest KBA had 143 individual native mother trees correspond to 52 species, Mount Lantoy KBA had 68 individual native mother trees correspond to 29 species and for Mount Capayas KBA had 31 individual native mother trees correspond to 16 species. We provide list of native species which can be used in the reforestation program as planting material with the rationale that it could reduce the risks of failure due to its high adaptability to the environment. This highly valued native species will also restore the original economic and ecological benefits to local communities.

\section{ACKNOWLEDGMENTS}

The authors would like to acknowledge the Department of Science and Technology (DOST) for considering and approving our research proposal and giving us the budget for three years for the implementation of the whole study, and declaring CTU as one of the DOST - Biodiversity center through NICER program in Region 7. The Philippine Consortium for Agriculture and Resource Research Development (PCAARRD) for recommending our proposal to DOST for approval and guide us in the implementation of the study, assisted us in the report preparation and writing. The CTU System for supporting the research team and allowing the research staff to conduct the study. The College of Forestry in CTU-Argao, Campus for allowing their students to participate in the gathering of data. The DENR Region 7 for giving us the Gratuitous permit (GP). The CENRO Argao and Cebu City for approving our request to conduct the study in different key Biodiversity Areas. The Municipalities of Argao, Dalaguete, Alcoy, Malabuyoc, Alegria and Catmon for allowing us to conduct the study in their area of responsibilities. The first author (EPL) thanks his wife (Mary Jane) and son (CJ) for their moral support during the study.

\section{REFERENCES}

Anitha K, Joseph S, Chandran RJ, Ramasamy EV, Prasad SN. 2010. Tree species diversity and community composition in a human-dominated tropical forest of Western Ghats biodiversity hotspot, India. Ecol Complex 7 (2): 217-224. DOI: 10.1016/j.ecocom.2010.02.005

Aronson J, Alexander S. 2013. Ecosystem restoration is now a global priority: time to roll up our sleeves. Restor Ecol 21 (3): 293-296. DOI: $10.1111 / \mathrm{rec} .12011$

Bonn Challenge. 2016. The Global Partnership on Forest Landscape Restoration. 2016. http:// www.bonnchallenge.org/.

Bozzano M, Jalonen R, Thomas E, Boshier D, Gallo L, Cavers S, Bordács S, Smith P, Loo J (eds) 2014. Genetic considerations in ecosystem restoration using native tree species. State of the World's Forest Genetic Resources - Thematic Study. Rome, FAO and Bioversity International.

Chazdon RL, Brancalion PH, Lamb D, Laestadius L, Calmon M, Kumar C. 2015. A policy-driven knowledge agenda for global forest and landscape restoration. Conserv Lett 10 (1): 125-132. DOI: $10.1111 /$ conl.12220

Conservation International. 2021. Philippines - Species. https://www.cepf.net/our-work/biodiversityhotspots/philippines/species

Co's Digital Flora of the Philippines. https://www.philippineplants.org/FamsAlph.html.

Daisuke H, Tanaka K, Joseph Jawa K, Ikuo N, Katsutoshi S. 2013. Rehabilitation of degraded tropical rainforest using Dipterocarp trees in Sarawak, Malaysia. Int $J$ For Res 1-11. DOI: $10.1155 / 2013 / 683017$.

DENR-DAO. 1995. Department Administrative Order No. 95-09 1995, Regulations on Forest Tree Seed Production, Collection and Disposition.

DENR NGP Website. http://ngp.denr.gov.ph/index.php/basicconfiguration/site-Administrator/ngp-accomplishment-report 
FMB DENR. 2015. Philippine Master Plan for Climate Resilient Forestry Development. http://forestry.denr.gov.ph/pdf/mp/pmpcrfd_2015 plus annexes.pdf

Fernando ES, Suh MN, Lee J, Lee DK. 2008. Forest formation of the Philippines. ASEAN - Korea Environmental Cooperation Unit (AKECU). GeoBook Publishing Co.

Global Forest Watch. 2020. Tree cover loss in Cebu, Philippines. https://www.globalforestwatch.org/blog/data-and-research/tree-coverloss-satellite-data

Hamann MCA. 2015. Choosing species for reforestation in diverse forest communities: social preference versus ecological suitability. Ecosphere 6 (11): 1-13. DOI: 10.1890/ES15-00131.1

Hansen MC, Potapov PV, Moore R, Hancher M, Turubanova SA, Tyukavina A, Thau D, Stehman SV, Goetz SJ, Loveland TR, Kommareddy A, Egorov A, Chini L, Justice CO, Townshend JRG 2013. High-resolution global maps of 21 st-century forest cover change. Science 342 (6160): 850-853. DOI: 10.1126/science.1244693

Hyvärinen M, Miranto M, Hiltunen R, Schulman L. 2011. Strategy and action plan for ex-situ conservation of threatened plants in Finland Action 11: assessment of the impacts of climate change on biodiversity in coastal ecosystems and the implementation of new policies and conservation strategies.

Jacobs DF, Oliet JA, Aronson J, Bolte A, Bullock JM, Donoso PJ, Landhausser SM, Madsen P, Peng S, Rey-Benayas Jm, Weber JC. 2015. Restoring forests: What constitutes success in the twenty-first century?. New Forests 46, 601-614 (2015). DOI: 10.1007/s11056015-9513-5

Keenan RJ, Reams GA, Achard F, de Freitas JV, Grainger A, Lindquist E. 2015. Dynamics of global forest area: results from the FAO global forest resources assessment 2015. For Ecol Manag 352: 9-20. DOI: 10.1016/j.foreco.2015.06.014

Kettle CJ. 2010. Ecological considerations for using dipterocarps for restoration of lowland rainforest in Southeast Asia. Biodivers Conserv 19, 1137-1151. DOI: 10.1007/s10531-009-9772-6.

Lestari DA, Fiqa AP, Fauziah F, Budiharta S. 2019. Growth evaluation of native tree species planted on post coal mining reclamation site in East Kalimantan, Indonesia. Biodiversitas 20 (1): 134-143. DOI: $10.13057 /$ biodiv/d200116

Lillo EP, Fernando ES, Lillo MJR. 2019. Plant diversity and structure of forest habitat types on Dinagat Island, Philippines. J Asia-Pac Biodivers 12 (1): 83-105. DOI: 10.1016/j.japb.2018.07.003

Lillo EP, Malaki ABB, Alcazar SMT, Nuevo RU, Rosales R. 2019. Native trees on Mount Lantoy Key Biodiversity Areas (KBA), Argao, Cebu, Philippines. Philippine J Sci 148 (2): 359-371.

Lillo EP, Malaki AB, Alcazar SMT, Rosales R, Redoblado BR, Pantinople E, Nuevo RU, Cutillar RC, Almirante A, Buot IE Jr. 2020.
Diversity and distribution of ferns in forest over limestone in Cebu Island Key Biodiversity Areas (KBAs), Philippines. Biodiversitas 21 (1): 413-421. DOI: $10.13057 /$ biodiv/d210148

Meli P, Martınez-Ramos M, Rey-Benayas JM, Carabias J. 2014. Combining ecological, social and technical criteria to select species for forest restoration. Appl Veg Sci 17 (4): 744-753. DOI: 10.1371/journal.pone. 0170418

Nichols JD, Vanclay JK. 2012. Domestication of native tree species for timber plantations: Key insights for tropical island nations. Int For Rev 14 (4): 402-413. DOI: $10.1505 / 146554812804715892$

Ostertag R, Warman L, Cordell S, Vitousek PM. 2015. Using plant functional traits to restore Hawaiian rainforest. J Appl Ecol 52 (4): 805-809. DOI: $10.1111 / 1365-2664.12413$

Schneider T, Ashton MS, Montagnini F, Milan PP. 2014. Growth performance of sixty tree species in smallholder reforestation trials on Leyte, Philippines. New For 45 (1): 83-96. DOI: 10.1007/s11056013-9393-5

Soejono, Budiharta S, Arisoesilaningsih A. 2013. Proposing local trees diversity for rehabilitation of degraded lowland areas surrounding springs. Biodiversitas 14 (1): 37-42. DOI: $10.13057 /$ biodiv/d140106

Stanturf JA, Palik BJ, Dumroese RK. 2014. Contemporary forest restoration: A review emphasizing function. For Ecol Manag 331: 292-323. DOI: $10.1016 /$ j.foreco.2014.07.029

Suding K, Higgs E, Palmer M, Callicott JB, Anderson CB, Baker M, et al. 2015. Committing to ecological restoration. Sci 348 (6235): 638-640. DOI: $10.1126 /$ science.aaa4216

Tropical Plants Database. 2021. Tropical Plants Database Ken Fern. tropical.theferns.info/viewtropical.php?id=Aquilaria+cumingiana

Van Breugel M, Hall JS, Craven DJ, Gregoire TG, Park A, Dent DH, Wishnie MH, Mariscal E, Deago J, Ibarra D, Cedeno N, Ashton MS. 2011. Early growth and survival of 49 tropical tree species across sites differing in soil fertility and rainfall in Panama. For Ecol Manag 261 (10): 1580-1589. DOI: 10.1016/j.foreco.2010.08.019

Wasli ME, Sani H, Ho SY, Perumal M, Zainudin ZA, Lat J, Sean LP. 2014. Preliminary assessment on the growth performance of Dryobalanops beccarii dyer planted under enrichment planting technique at Gunung Apeng Forest Reserve, Sarawak, Malaysia. Kuroshio Sci 8-1, 45-52.

Widiyatno, Na'iem M, Kanzaki M, Purnomo S, Jatmoko. 2013. Application of silviculture treatment to Support Rehabilitation on Loggedover Area (LOA) of Tropical Rainforest, Central Kalimantan, Indonesia. Int J Sustain Future Human Security 1: 50-55. DOI: 10.13057/biodiv/d170233

Wingfield M, Brockerhoff E, Wingfield B, Slippers B. 2015. Planted forest health: The need for a global strategy. Science 349 (6250): 832-836. DOI: 10.1126/science.aac6674 